\title{
ESCHERICHIA COLI RESISTEN ANTIBIOTIK ASAL AIR KERAN DI KAMPUS ISTN
}

\author{
Fathin Hamida ${ }^{1}$, Lisana Sidqi Aliya ${ }^{2}$, Vilya Syafriana ${ }^{3}$ dan Della Pratiwi $^{4}$ \\ 1,2,3,4 Program Studi Farmasi Fakultas Farmasi Institut Sains dan Teknologi \\ Nasional, Jl. Moch. Kahfi 2 Bhumi Srengseng Sawah, Jagakarsa, Jakarta \\ Selatan.
}

Email: ${ }^{1}$ fathinfarmasi@istn.ac.id, ${ }^{2}$ lisana.aliya@istn.ac.id, 3v.syafriana@istn.ac.id, ${ }^{4}$ dellaaapratiwi@gmail.com

\begin{abstract}
ABSTRAK
Resistensi antibiotik menjadi masalah global yang menyebar luas di dunia. Lingkungan merupakan jalur transmisi dan menyebabkan resistensi antibiotik. Hal itu dapat disebabkan oleh buruknya infrastruktur limbah air dan kontaminasi fekal. Kontaminasi air berpengaruh buruk bagi kesehatan manusia. Kampus ISTN memiliki pipa saluran air keran yang jarak berdekatan dengan pipa septic tank, jarak antara pipa air keran dengan pipa septic tank berkisar $\leq 11$ meter. Kontaminasi air oleh Escherichia coli menjadi factor penurunan kualitas air. Penelitian ini bertujuan mengisolasi E. coli dari pipa air keran kampus ISTN dan mendeteksi resistensinya terhadap antibiotik. Empat isolate $E$. coli telah diisolasi menggunakan media Lactose Broth dan Chromogenic Coliform Agar. Empat isolat E. coli telah diidentifikasi secara biokimiawi. Empat isolate $E$. coli diuji sensitivitasnya terhadap antibiotik amoksisilin, tetrasiklin, kloramfenikol, dan siprofloksasin menggunakan metode difusi cakram. Sensitivitas antibiotik diinterpresikan berdasarkan standar CLSI (Clinical and Laboratory Standard Institute). Hasil menunjukkan bahwa isolat 1A, 2A, 3A, dan 4A resisten terhadap amoksisilin, dan isolat $1 \mathrm{~A}$ bersifat intermediat.
\end{abstract}

Kata kunci : Escherichia coli, air, resistensi, antibiotic, difusi cakram

\begin{abstract}
Antibiotic resistance has become a global issue in wide world. Environment is transmission track and caused antibiotic resistance. It was caused by poor wastewater infrastructure and fecal contamination. Water contamination is a poor influence on human health. ISTN (National Science and Technology Institute) campus have landwater pipes that were closed to septic tank pipes, the distance between water pipes and septic tank
\end{abstract}


pipes were $\leq 11$ meters. These raises concerns to water quality. Water contaminated by Escherichia coli will become one factor of water low quality. This research was aimed to isolation Escherichia coli from landwater of ISTN campus and detecting their antibiotic resistance. Four samples were collected from four locations in the ISTN campus environment, it was 1A, 2A, 3A, and 4A. Four Escherichia coli isolates were isolated from the ISTN campus landwater. Isolation was using Lactose Broth and Chromogenic Coliform Agar media. Four Escherichia coli isolates were identified by biochemichal assay. Four Escherichia coli isolates were treated by Amoxycilin, Tetracyclin, Chloramphenicol, and Ciprofloxacin antibiotic use disc diffusion method. Antibiotic sensitivity was interpreted by the CLSI 2012 standard. The result showed that 2A, 3A, and 4A isolates were resistant to Amoxycilin, and $1 \mathrm{~A}$ isolates were intermediate to Amoxycilin.

Keywords: Escherichia coli, water, resistance, antibiotic, disc diffusion.

\section{PENDAHULUAN}

Escherichia coli adalah bakteri batang Gram negatif, fakultatif anaerob, dan merupakan anggota Enterobacteriaceae (Brooks dkk,2007). E. coli merupakan mikroflora normal pada usus, namun dapat menjadi patogen pada kondisi tertentu. E. coli sebagai bakteri patogen sering ditemukan sebagai bakteri penyebab infeksi saluran kemih (Kumala dkk, 2009; Prabowo dan Habib, 2012), infeksi saluran pencernaan (Sujaya dkk, 2010; Robins-Browne dkk, 2004; Schuetz, 2019), dan terlibat dalam infeksi luka pasca operasi (Alharbi dkk, 2018).

E. coli digunakan sebagai indikator kualitas air. E. coli secara normal hanya ditemukan di saluran pencernaan manusia atau hewan, atau bahan yang telah terkontaminasi dengan tinja manusia atau hewan. Berdasarkan hasil penelitian di Instalasi Rawat Khusus RSUP Dr. Wahidin
Sudirohisodo Makassar ditemukan beberapa bakteri pada air salah satunya adalah bakteri Escherichia coli sebesar 20\% (Taslim dan Maskoen, 2016). Sebesar $80 \%$ Escherichia coli resisten terhadap amoksisilin dan $20 \%$ resisten terhadap kloramfenikol berasal dari air sungai. Sebesar $66,7 \%$ Escherichia coli resisten terhadap amoksisilin dan $6.7 \%$ resisten terhadap kloramfenikol dari air rumah tangga (Sasongko, 2014). Air yang tercemar $E$. coli dianggap berbahaya bagi penggunaan domestik (Sumampouw dan Risjani, 2014). Air yang berkualitas baik adalah air yang memenuhi baku mutu air minum sebagaimana ditetapkan oleh Peraturan Menteri Kesehatan RI No 492/MENKES/PER/IV/2010.

Pipa saluran air keran yang berada di lingkungan Kampus ISTN memiliki jarak kurang dari 15 meter dengan jarak septic tank, sehingga dikhawatirkan air yang digunakan untuk memenuhi kebutuhan harian menjadi tercemar oleh bakteri E. coli. 
Sumber air ini salah satunya sering digunakan untuk memenuhi kebutuhan kantin dan akifitas di masjid Kampus ISTN yang biasa digunakan untuk berwudhu. Berdasarkan Peraturan Menteri PUPR No. 20/PRT/M/2016 tentang sistem penyelenggaran pada air jarak sumur harus > 15 meter dari sumber pencemaran seperti kakus, empang, lubang galian sampah, lubang galian kotor dan lain-lain, serta letak sumur harus lebih tinggi dari sumber pengotoran untuk menghindari kontaminasi air. Penelitian ini bertujuan mengisolasi bakteri E. coli dari air keran Kampus ISTN Jagakarsa, serta menguji sensitivitasnya terhadap antibiotik amoksisilin, tetrasiklin, kloramfenikol, dan siprofloksasin.

\section{METODE PENELITIAN}

\section{Penentuan Lokasi Pengambilan Sampel Air}

Empat sampel air keran diperoleh dari empat titik lokasi berbeda yang berada di Kampus ISTN Jagakarsa, Jakarta Selatan. Pengambilan sampel ditentukan berdasarkan jarak pipa air dengan saluran pembuangan tinja (septic tank). Empat titik lokasi pengambilan sampel sebagai berikut :

1. Sampel 1A : Sumber air yang diambil dari kantin di Kampus ISTN Jagakarsa (Dekat pos satpam).

2. Sampel 2A: Sumber air yang diambil dari kantin di Kampus ISTN Jagakarsa (Belakang Auditorium).

3. Sampel 3A: Sumber air yang diambil dari tempat wudhu laki - laki Masjid Bilal ISTN Jagakarsa.
4. Sampel 4A : Sumber air yang diambil dari tempat wudhu perempuan Masjid Bilal ISTN Jagakarsa.

Sampel air diambil langsung dari keran air dan dimasukkan ke dalam botol kaca steril, pengambilan sampel air dilakukan sebanyak 5 kali pengulangan dari setiap titik lokasi, kemudian air yang ditempatkan pada botol kaca ditutup rapat.

\section{Isolasi Escherichia coli}

Sebanyak $1 \mathrm{~mL}$ sampel air diinokulasi ke dalam $5 \mathrm{~mL}$ media LB (Lactose Broth) kemudian diinkubasi selama 24 jam pada suhu $37{ }^{0} \mathrm{C}$. Hasil positif pertumbuhan E. coli dan koliform ditandai dengan tampak gelembung gas yang terperangkap di dalam tabung durham. Isolasi dilanjutkan dengan inokulasi sampel LB positif ke media CCA (Chromocult Coliform Agar (CCA) dengan cara gores kuadran lalu diinkubasi selama 24 jam pada suhu $37{ }^{0} \mathrm{C}$. Hasil positif pertumbuhan E. coli pada media CCA ditandai dengan koloni tunggal tumbuh berwarna biru violet. Koloni tumbuh berwarna biru violet diambil sebanyak 1 ose kemudian ditanam pada media agar miring Nutrient Agar (NA), lalu diinkubasi pada suhu $37^{\circ} \mathrm{C}$ selama 24 jam, dan disimpan dalam lemari es sebagai kultur stok.

\section{Identifikasi Escherichia coli}

Identifikasi E. coli dilakukan pada setiap isolat hasil isolasi asal air keran. Identifikasi mikroskopik dilakukan dengan pewarnaan Gram dan identifikasi aktifitas biokimiawi. Identifikasi aktifitas biokimiawi meliputi: uji katalase, uji produksi Indol, uji pemanfaatan sitrat, dan uji fermentasi karbohidrat. 
Uji Sensitivitas Escherichia coli terhadap Antibiotik dengan Metode Difusi Cakram

Uji sensitivitas antibiotik dilakukan menggunakan metode difusi cakram. Sebanyak $0.1 \mathrm{~mL}$ suspensi isolat bakteri E. coli berumur 24 jam

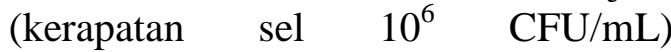
diinokulasi ke media Mueller Hinton Agar (MHA) dan disebar dengan batang sebar. Kemudian cakram antibiotik diletakkan diatas permukaan media MHA lalu diinkubasi pada suhu $37{ }^{0} \mathrm{C}$ selama $24 \mathrm{jam}$. Diameter zona hambat yang terbentuk disekililing cakram diukur dengan jangka sorong. Uji sensitivitas dilakukan 3 kali ulangan masing - masing ulangan dibuat triplo. Rata - rata diameter zona hambat diinterpretasikan berdasarkan interpretasi sensitivitas antibiotic Clinical Laboratory Standard Institute (CLSI, 2012)

\section{Analisis Data}

Data isolasi, identifikasi, dan sensitivitas antibiotik diolah secara deskriptif.

\section{HASIL DAN PEMBAHASAN}

\section{Isolasi Escherichia coli}

Tabel 1 menunjukkan bahwa pada media LB diperoleh hasil positif koliform. Hal ini ditandai dengan terbentuknya gelembung gas yang terperangkap pada tabung durham setelah inkubasi 24 jam pada suhu $37^{\circ} \mathrm{C}$. Media LB mengandung pepton, beef extract, dan laktosa. Pepton dan beef extract menyediakan nutrient essential untuk metabolisme bakteri, sedangkan laktosa dapat dimanfaatkan oleh bakteri koliform sebagai sumber karbohidrat. (Kusuma dkk, 2015).
Tabel 1. Hasil inokulasi sampel air pada Media LB dari sampel air keran setelah inkubasi 24 jam pada suhu $37^{\circ} \mathrm{C}$.

\begin{tabular}{cc}
\hline Sampel & Hasil \\
\hline 1A & $(+)$ Koliform \\
2A & $(+)$ Koliform \\
3A & (+) Koliform \\
4A & (+) Koliform \\
Kontrol positif & (+) Koliform \\
\hline
\end{tabular}

Keterangan:

1A: Kantin Kampus (Dekat pos satpam)

2A: Kantin Kampus (Belakang Auditorium)

3A: Tempat wudhu Masjid Bilal (Laki laki)

4A: Tempat wudhu Masjid Bilal (Perempuan)

Isolasi dilanjutkan dengan purifikasi koloni tunggal diduga $E$. coli pada media CCA. Media CCA adalah media selektif diferensial yang dapat mendeteksi pertumbuhan bakteri koliform dan E. coli.

Media CCA (Chromocult Coliform Agar) merupakan media diferensial untuk membedakan bakteri E. coli dengan bakteri koliform lainnya. Prinsipnya yaitu berdasarkan kemampuan bakteri menghasilkan enzim B-D-galactosidase dan enzim BD-glucuronidase. Media CCA mengandung dua substrat kromogenik yaitu Salmon-GAL (6-chloro-3indoxyl-beta-D-galactopyranoside) dan $X$-beta-D-Glucuronide (5-Bromo-4chloro-3-indoxyl- $\beta$-Dglucuronic acid, cyclohexylammonium salt monohydrate). Media CCA merupakan media selektif yang digunakan untuk mendeteksi bakteri koliform dan $E$. coli. Media ini mengandung ekstrak ragi, sodium piruvat, sodium klorida, sodium dihidrogen fosfat, sorbitol, 
tergitol, dan substrat kromogenik (Salmon-GAL dan X-Glucuronidae). Tergitol berfungsi untuk menghambat pertumbuhan bakteri Gram positif dan beberapa Gram negatif tetapi tidak mempengaruhi pertumbuhan bakteri koliform. Ekstrak ragi, sodium piruvat, disodium hidrogen fosfat, sodium dihidrogen fosfat dan sorbitol berfungsi mempercepat pertumbuhan koliform (Byamukama dkk, 2000; Lange dkk., 2013). Hasil isolasi E. coli pada media cawan CCA menunjukkan terdapat $E$. coli pada sampel air yang ditandai dengan pertumbuhan koloni berwarna biru violet (Gambar 1).

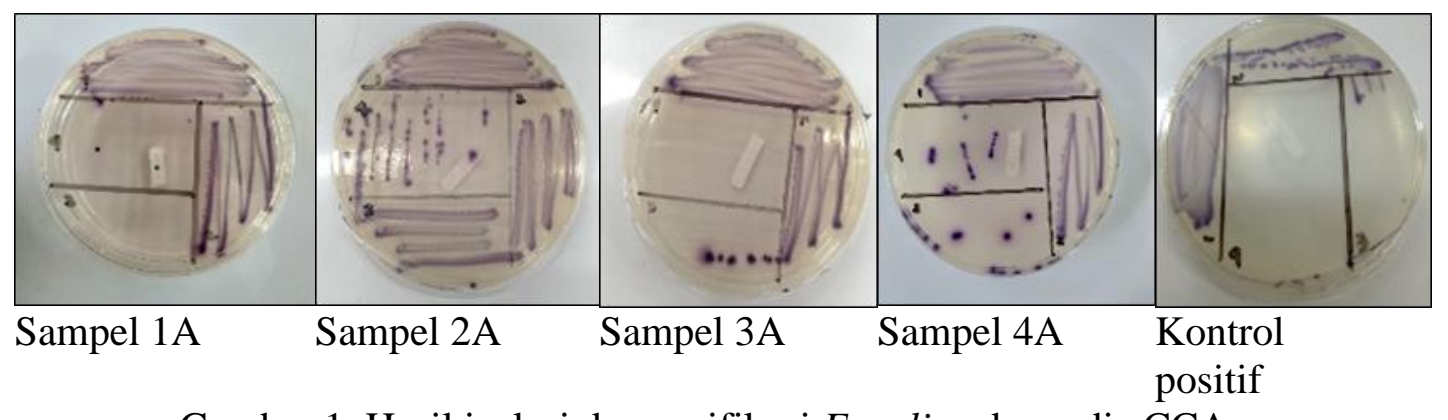

Gambar 1. Hasil isolasi dan purifikasi E. coli pada media CCA

Media CCA (Chromocult Coliform Agar) merupakan media diferensial untuk membedakan bakteri E. coli dengan bakteri koliform lainnya. Prinsipnya yaitu berdasarkan kemampuan bakteri menghasilkan enzim $ß-\mathrm{D}$-galactosidase dan enzim $\beta$ D-glucuronidase. Media CCA mengandung dua substrat kromogenik yaitu Salmon-GAL (6-chloro-3indoxyl-beta-D-galactopyranoside) dan X-beta-D-Glucuronide (5-Bromo-4chloro-3-indoxyl- $\beta$-Dglucuronic acid, cyclohexylammonium salt monohydrate). Media CCA merupakan media selektif yang digunakan untuk mendeteksi bakteri koliform dan $E$. coli. Media ini mengandung ekstrak ragi, sodium piruvat, sodium klorida, sodium dihidrogen fosfat, sorbitol, tergitol, dan substrat kromogenik (Salmon-GAL dan X-Glucuronidae). Tergitol berfungsi untuk menghambat pertumbuhan bakteri Gram positif dan beberapa Gram negatif tetapi tidak mempengaruhi pertumbuhan bakteri koliform. Ekstrak ragi, sodium piruvat, disodium hidrogen fosfat, sodium dihidrogen fosfat dan sorbitol berfungsi mempercepat pertumbuhan koliform (Byamukama dkk, 2000; Lange dkk., 2013).

Bakteri koliform anggota
Enterobacteriaceae (Citrobacter, Enterobacter, dan Klebsiella) mampu menghasilkan enzim $\beta$-galactosidase yang dapat mendegradasi substrat Salmon-GAL menjadi senyawa kromogenik sehingga koloni yang tumbuh pada media CCA berwarna merah salmon. Genus Shigella, Salmonella, dan Yersinia tidak dapat menghasilkan enzim $\beta$-galactosidase namun dapat menghasilkan enzim $\beta$-Dglucuronidase menjadi senyawa kromogenik sehingga koloni yang tumbuh pada media CCA berwarna biru muda hingga toska. E. coli mampu menghasilkan enzim $\beta$-galactosidase dan $\beta$-D-glucuronidase, enzim $\beta$ - 
galactosidase mendegradasi SalmonGAL dan $\beta$-D-glucuronidase mendegradasi substrat X-glucuronida menghasilkan produk senyawa kromogenik sehingga koloni yang tumbuh pada media CCA berwarna biru tua. Bakteri Gram negatif lainnya non koliform tidak memiliki $\beta$ galactosidase dan $\beta$-D-glucuronidase sehingga koloni yang tumbuh pada media CCA tidak berwarna (colorless) karena tidak dapat mendegradasi Salmon-GAL menjadi senyawa koromogenik dan X-glucuronida menjadi X dan Glucuronida (Rice dkk, 1990; Tryland dan Fiksdal, 1998). Warna koloni disebabkan oleh reaksi enzimatis yang mengubah substrat kromogenik menjadi produk senyawa berwarna. Warna yang terbentuk merupakan hasil reaksi enzimatik yang spesifik untuk masing - masing genus (Turner dkk., 2000; Finney dkk, 2003).

\section{Identifikasi Mikroskopik dengan Pewarnaan Gram}

Berdasarkan hasil identifikasi mikroskopik diperoleh bahwa empat isolat berbentuk basil pendek dan tipe reaksi gram adalah Gram negatif.
Reaksi Gram dibedakan berdasarkan komponen penyusun dinding sel bakteri. Bakteri Gram negatif adalah kelompok bakteri yang memiliki dinding sel tersusun oleh $10 \%$ peptidoglikan, membran luar, dan periplasma. Empat isolat asal air keran memiliki sifat aktifitas biokimiawi yang menunjukkan E. coli yaitu katalase positif, indol positif, sitrat negatif, fermentasi karbohidrat positif, motil, dan negatif $\mathrm{H}_{2} \mathrm{~S}$ (Tabel 2).

Katalase positif menunjukkan bahwa E. coli mampu menghasilkan enzim hidrogen peroksidase selama pertumbuhannya. Indol positif menunjukkan bahwa E. coli mampu menghasilkan enzim triptofanase untuk mendegradasi triptofan menjadi indol. Sitrat negatif menunjukkan bahwa $E$. coli tidak mampu memanfaatkan sitrat sebagai satu - satunya sumber karbon karena tidak dapat menghasilkan enzim sitrat permease. E. coli mampu memfermentasi tiga jenis gula pada media TSIA (Triple Sugar Iron Agar), dan tidak dapat memanfaatkan sulfida sehingga tidak menghasilkan $\mathrm{H}_{2} \mathrm{~S}$ (Jorgensen dkk, 2015).

Tabel 2. Hasil Identifikasi Aktifitas Biokimiawi Isolat E.coli asal air keran

\begin{tabular}{ccccccc}
\hline Kode Isolat E. coli & $\mathrm{K}$ & $\mathrm{I}$ & $\mathrm{M}$ & $\mathrm{Su}$ & $\mathrm{Si}$ & $\mathrm{C}$ \\
\hline 1A & + & + & + & - & - & + \\
2A & + & + & + & - & - & + \\
3A & + & + & + & - & - & + \\
4A & + & + & + & - & - & + \\
Kontrol positif & + & + & + & - & - & + \\
\hline
\end{tabular}

Keterangan:

$\mathrm{K}$ : uji katalase dengan pereaksi $\mathrm{H}_{2} \mathrm{O}_{2}$

I: uji produksi indol menggunakan media SIM (Sulfide Indole Motility)

M: uji motilitas menggunakan media SIM

$\mathrm{Su}$ : uji produksi $\mathrm{H}_{2} \mathrm{~S}$ menggunakan media SIM

Si: uji pemanfaatan sitrat menggunakan media Simmon's Citrate Agar

C: uji fermentasi karbohidrat menggunakan media TSIA (Triple Sugar Iron Agar) 


\section{Uji Sensitivitas Antibiotik}

Tabel 3. Rata - Rata Diameter Zona Hambat dengan Metode Difusi Cakram

\begin{tabular}{lllll}
\hline Kode Isolat $E$. coli & AML $(25 \mu \mathrm{g})$ & TE $(30 \mu \mathrm{g})$ & $\mathrm{C}(5 \mu \mathrm{g})$ & $\mathrm{CIP}(5 \mu \mathrm{g})$ \\
\hline 1A & $15,75(\mathrm{I})$ & $19,7(\mathrm{~S})$ & $23,12(\mathrm{~S})$ & $23,38(\mathrm{~S})$ \\
2A & $12,45(\mathrm{R})$ & $18,55(\mathrm{~S})$ & $23,8(\mathrm{~S})$ & $28,52(\mathrm{~S})$ \\
3A & $10,98(\mathrm{R})$ & $18,53(\mathrm{~S})$ & $22,22(\mathrm{~S})$ & $23,56(\mathrm{~S})$ \\
4A & $11,34(\mathrm{R})$ & $17,05(\mathrm{~S})$ & $23,56(\mathrm{~S})$ & $26,37(\mathrm{~S})$ \\
\hline
\end{tabular}

Keterangan : AML $=$ Amoksisilin $(\mathrm{S}: \geq 17 \mathrm{~mm}, \mathrm{I}: 15-16 \mathrm{~mm}, \mathrm{R}: \leq 14 \mathrm{~mm}) ; \mathrm{TE}=$ Tetrasiklin (S: $\geq 15 \mathrm{~mm}, \mathrm{I}: 12-14 \mathrm{~mm}, \mathrm{R}: \leq 11 \mathrm{~mm}) ; \mathrm{C}=$ Kloramfenikol (S: $\geq 18 \mathrm{~mm}$, I: $13-$ $17 \mathrm{~mm}, \mathrm{R}: \leq 12 \mathrm{~mm})$; CIP $=$ Siprofloksasin (S: $\geq 21 \mathrm{~mm}, \mathrm{I}: 16-20 \mathrm{~mm}, \mathrm{R}: \leq 15 \mathrm{~mm})$. (Clinical and Laboratory Standards Institute (CLSI, 2012)).

Tabel 3 menunjukkan bahwa seluruh isolat $E$. coli asal air keran dapat dihambat oleh antibiotik uji dengan respon berbeda. Seluruh isolat E. coli menunjukkan sensitif terhadap tetrasiklin, kloramfenikol, dan siprofloksasin. Isolat $E$. coli 1A ditemukan bersifat intermediet, artinya isolat tersebut memiliki sensitivitas yang lebih rendah terhadap amoksisilin. Isolat $E$. coli $2 \mathrm{~A}, 3 \mathrm{~A}$, dan 4A ditemukan bersifat resisten terhadap amoksisilin, artinya ketiga isolat tersebut tidak lagi sensitif terhadap amoksisilin (CLSI, 2012). Amoksisilin merupakan antibiotik yang umum diresepkan oleh dokter pada pasien penderita infeksi saluran pencernaan dan infeksi saluran kemih (Kumala dkk, 2009). Berdasarkan hasil uji sensitivitas ditemukan bahwa sebagian besar isolat telah resisten terhadap amoksisilin, hal ini diduga akibat jarak sumber air dengan septic tank yang berdekatan beresiko mencemari air bersih. Sampel 1A jarak antara sumur dengan septic tank 11 meter, Sampel 2A jarak antara sumur dengan septic tank 8,9 meter, Sampel 3A jarak antara sumur dengan septic tank 9,65 meter, Sampel 4A jarak antara sumur dengan septic tank 5,6 meter. Hal ini menunjukkan bahwa jarak antara sumur dengan septic tank kurang dari
15 meter dapat mempengaruhi kualitas air (Awuy dkk, 2018). Semakin dekat jarak sumber pencemar (septic tank) dengan sumur maka semakin tinggi populasi E. coli (Sapulete, 2010). Jarak sumber air dengan septic tank mempengaruhi populasi mikroorganisme pada hasil Angka Lempeng Total (Awuy dkk, 2018). Belakangan ini E. coli resisten antibiotik terutama resisten terhadap amoksisilin sering ditemukan sebagai bakteri pencemar air (Sasongko, 2014). Cemaran ini di duga akibat kontaminasi air dengan urin atau tinja yang telah terkontaminasi dengan $E$. coli yang telah resisten terhadap antibiotik. Air yang berkualitas baik adalah air yang memenuhi baku mutu air minum yang ditetapkan oleh Peraturan Menteri Kesehatan RI No 492/MENKES/PER/IV/2010, meliputi persyaratan fisika, kimia dan biologi, air tersebut harus bebas dari mikroorganisme patogen dan bahan kimia berbahaya (Wulandari dkk, 2014).

\section{KESIMPULAN}

Seluruh sampel air di Kampus ISTN Jagakarsa, Jakarta Selatan tercemar bakteri Escherichia coli. Isolat Escherichia coli dari sampel air 
2A, 3A, dan 4A resisten terhadap UCAPAN TERIMAKASIH antibiotik amoksisilin.

\author{
Ucapan terimakasih diberikan \\ pada KEMENRISTEKDIKTI atas \\ bantuan dana hibah penelitian PDP \\ (Penelitian Dosen Pemula) tahun 2018.
}

\title{
DAFTAR PUSTAKA
}

Alharbi, N.S, Khaled, J.M., Kadaikunnan, S., Alobaidi, A.S., Sharafaddin, A.H., Alyahya, S.A., Almanaa, T.N., Alsughayier, M.A., Shehu, M.R. (2018). Prevalence of Escherichia coli strains resistance to antibiotics in wound infections and raw milk. Saudi Journal of Biological Sciences. https://doi.org/10.1016/j.sjbs.2018.11.016.

Awuy, S.C, Sumampouw, O.J., Boky, B. (2018). Kandungan Escherichia coli pada air sumur gali dengan septic tank di kelurahan Rap-Rap kabupaten Minahasa Utara tahun 2018. Jurnal Kesmas. 7(4): 1-6.

Brooks, G.F., Carroll, K.C., Butel, J.S., Morse, S.A. (2007). Jawetz, Melnick, \& Adelberg's: Medical Microbiology. 24 ${ }^{\text {th }}$ Ed. McGraw-Hill Medical. New York.

Byamukama, D., Kansiime, F., March, R.L., Farnleitner, A.H. (2000). Determination of Escherichia coli contamination with Chromocult Coliform Agar showed a high level of discrimination efficiency for differening fecal pollution levels in tropical waters of Kampala, Uganda. Appl. Environ. Microbiol. 66: 864-868.

Clinical dan Laboratory Standards Institute. (2012). Performance Standards for Antimicrobial Susceptibility Testing : Twenty-Second Informational Supplement. M100-S22. 32(3).

Finney, M., Smullen, J., Foster, H.A, Brokx, S., Storey, D.M. (2003). Evaluation of chromocult coliform agar for the detection and enumeration of Enterobacteriaceae from faecal samples from healthy subjects. Journal of Microbiological Methods. 54: 353- 358. doi:10.1016/S01677012(03)00068-X.

Jorgensen, J.H., Pfaller, M.A., Carroll, K.C., Funke, G., Landry, M. L., Richter, S.S., Warnock, D.W. (2015). Manual of Clinical Microbiology, $11^{\text {th }}$ Edition. ASM Press. Washington DC.

Kumala, S., Raisa, N., Rahayu, L., Kiranasar, A. (2009). Uji kepekaan bakteri yang diisolasi dari urin penderita infeksi saluran kemih (Isk) terhadap beberapa antibiotika pada periode Maret-Juni 2008. Majalah Ilmu Kefarmasian. VI( 2): 45 - 55.

Kumala, S., Raisa, N., Rahayu, L., Kiranasari, A. (2009). Uji kepekaan bakteri yang diisolasi dari urin penderita infeksi saluran kemih (isk) terhadap beberapa antibiotika pada periode Maret - Juni 2008. Majalah Ilmu Kefarmasian. VI(2): $45-55$. 
Kusuma, E.A., Rasyid, R., Endrinaldi. (2015). Identifikasi bakteri Coliform pada air kobokan di rumah makan kelurahan Andalas kecamatan Padang Timur. Jurnal Kesehatan Andalas. 4(3): 845.

Lange, B., Strathmann, M., Oßmer, R. (2013). Performance validation of chromogenic coliform agar for the enumeration of Escherichia coli and coliform bacteria. Lett. Appl. Microbiol. 57: 547-553.

Prabowo, F.I dan Habib, I. (2012). Identifikasi pola kepekaan dan jenis bakteri pada pasien infeksi saluran kemih di Rumah Sakit PKU Muhammadiyah Yogyakarta. Mutiara Media Jurnal Kedoteran dan Kesehatan. 12 (2): 93 101.

Rice, E.W., Allen, M. J., Edberg, S.C. (1990). Efficacy of $\beta$-Glucuronidase assay for identification of Escherichia coli by the defined-substrate technology. Applied and Environmental Microbiology. 56(5): 1203-1205.

Robins-Browne, R.M., Bordun, A.M., Tauschek, M., Bennett-Wood, V.R., Russell, J., Oppedisano, F., Lister, N.A., Bettelheim, K.A, Fairley, C.K, Sinclair, M.I., Hellard, M.E. (2004). Escherichia coli and community acquired gastroenteritis, Melbourne, Australia. Emerging Infectious Diseases. 10(10): 1797 - 1805.

Sapulete. (2010). Hubungan antara jarak septic tank ke sumur Gali dan kandungan Escherichia coli dalam air sumur Gali di kelurahan Tuminting kecamatan Tuminting Kota Manado. Jurnal Biomedik. 2(3):179- 186.

Sasongko, H. (2014). Uji resistensi bakteri Escherichia Coli dari sungai Boyong kabupaten Sleman terhadap antibiotik amoksisilin, kloramfenikol, sulfametoxasol, dan streptomisin. Jurnal Bioedukatika. 2(1): 25-29. doi: 10.26555/bioedukatika.v2i1.4108.

Schuetz, A.N. (2019). Emerging agents of gastroenteritis: Aeromonas, Plesiomonas, and the diarrheagenic pathotypes of Escherichia coli. Seminars in Diagnostic Pathology. 36(3): 187-192. https://doi.org/10.1053/j.semdp.2019.04.012.

Sujaya, I.N., Aryantini, N.P.D., Nursini, N.W., Purnama, S.G., Dwipayanti, N.M.U, Artawan, I.G., Sutarga, I.M. (2010). Identifikasi penyebab diare di kabupaten Karangasem, Bali. KESMAS, Jurnal Kesehatan Masyarakat Nasional. 4(4): 186-192.

Sumampouw, O.J., dan Risjani, Y. (2014). Bacteria as indicators of environmental pollution. International Journal of Ecosystem. 4(6): 251-258. doi : 10.5923/j.ije.20140406.03.

Taslim, E., dan Maskoen, T.T. (2016). Pola kuman terbanyak sebagai agen penyebab infeksi di intensive care unit pada beberapa rumh sakit di Indonesia. Anesthesia \& Critical Care. 34 (1): 56-62.

Tryland, I dan Fiksdal, L. (1998). Enzyme characteristics of $\beta$-D-Galactosidaseand $\beta$-D-Glucuronidase-positive bacteria and their interference in rapid methods for detection of waterborne Coliforms and Escherichia coli. Applied and Environmental Microbiology. 64(3): 1018-1023.

Turner, K.M., Restaino, L., Frampton, E.W. (2000). Efficacy of chromocult coliform agar for Coliform and Escherichia coli detection in foods. Journal of Food Protection. 63(4): 539-541. 
Jurnal Kesehatan. Vol. 12. No. 1. Juni 2019. ISSN 1979-7621 (Print). ISSN 2620-7761 (Online).

Wulandari, C., Nasril, N., Anthoni, A. (2014). Kondisi bakteriologis air sumur di sekitar tempat pembuangan akhir air dingin kota Padang. Jurnal Biologi Universitas Andalas. 3(4): 289 - 295. 